\title{
THE COMPARISON OF TOTAL PHENOLIC CONTENT, ANTIOXIDANT CAPACITY AND MOLECULAR ANALYSIS OF SOME SELECTED TURKISH APPLE (MALUS SPP.) GENOTYPES
}

\author{
INAL, B. ${ }^{1}-$ OZRENK, K. ${ }^{2 *}-$ EREZ, M. E. ${ }^{3}-$ ALTINTAS, ${ }^{2}$ \\ ${ }^{1}$ Department of Agricultural Biotechnology, University of Siirt \\ Siirt, Turkey \\ ${ }^{2}$ Department of Horticulture, University of Siirt \\ Siirt, Turkey \\ ${ }^{3}$ Department of Biology, University of Siirt \\ Siirt, Turkey \\ *Corresponding author \\ e-mail: korayozrenk@siirt.edu.tr \\ (Received 19 ${ }^{\text {th }}$ Jul 2017; accepted 29 $9^{\text {th }}$ Sep 2017)
}

\begin{abstract}
In the present study, eight apple genotypes were analyzed using internal cpDNA trnL intron sequence. Furthermore, these genotypes species were evaluated for their antioxidant activity, total phenolic and flavonoid contents. Genotypes in question show quite a variation in biochemical characteristics and molecular systematic analysis. One of the genotypes "Helesan" was the best graded genotype based on the high content of the total phenolic $(12,21 \pm 1,25)$ and total flavonoid $(7,98 \pm 0,26)$ content. As a result of the molecular analysis, which is one of the main aims of the study, genotypes are comprised of three main clades with robust bootstrap (95) value. It was concluded that these genotypes could be useful to improve genetic diversity among genotypes for breeding.
\end{abstract}

Keywords: antioxidant; Malus sp.; cpDNA trnL; molecular systematic

\section{Introduction}

Hundreds of clinical trials and epidemiological studies have been carried out to investigate the effect of diet on health. Although not all studies show a link between vegetable and fruit and health, in a major part of them, positive correlation is observed between vegetable, fruit consumption and health and reduced risk of some chronic diseases such as cancer, cardiovascular diseases (Arts and Hollman, 2005; Boyer and Liu, 2003; Lampe, 1999). This association partially may be due to the antioxidant compounds present in fruits showing protective effect on the cell against oxidative effect caused by reactive oxygen species (ROS) and reactive N species (RNS) (Arts and Hollman, 2005; Henríquez et al., 2010; Scalbert et al., 2005). Therefore, it is very important to consume foods rich in antioxidants. These compounds may reduce oxidative stress through a number of mechanisms (Kalinowska et al., 2014). The total antioxidant capacity of fruit extracts was measured by using spectrophotometric approaches with DPPH (2,2-diphenyl-1-picrylhydrazyl) (Rivero-Pérez et al., 2007). DPPH method is based on the electron transfer from an antioxidant to a free radical (Duarte-Almeida et al., 2006).

Apple (Malus $\times$ domestica Borkh.) is among the commonly consumed fruits. In Turkey, apple production has reached to 2.57 million ton/year (Bugem). Apple makes up a significant part of human diet as they have sugars, acids and a number of 
biologically active compounds such as phenolic and flavonoid compound (Boyer and Liu, 2003; Lampe, 1999; Wu et al., 2007). There is a strong link between phenolic content of apple and antioxidant activity. The main phenolics acid found in apple is chlorogenic acid and this compound has the ability to scavenge free radicals (Panzella et al., 2013). The concentration of these phytochemicals including phenolics and flavonoids compounds greatly depends on the apple genotype and the maturity stage of the apples and is closely related to their nutritional and sensory properties $(\mathrm{Wu}$ et al., 2007).

Though there are over 7,000 apple genotypes known across the globe, nowadays the world's production is based on a limited number of genotypes (Hokanson et al., 2001; Patzak et al., 2012). Therefore, A genetic characterization of the apple genotypes plays a key role in breeding programs, patent protection and nursery control (Goulão and Oliveira, 2001; Smolik et al., 2004). The recent advances in DNA technology have provided several methods which may be employed for the characterization of apple germplasm collections (Patzak et al., 2012). The trnL-F region, consisted of the trnL intron and trnL-F spacer, has been among the commonly used chloroplast markers for phylogenetic analyses in plants. The trnL-F region has been found to be useful in molecular phylogenetic studies of a broad range of plant groups (Pirie et al., 2007; Quandt et al., 2004).

Therefore, the aim of this study is: (a) to determine the total phenolic and flavonoid contents and the antioxidant activity of the eight native apple genotypes, (b) to assess the phylogenetic relationship between genotypes by alignments of DNA sequences from cpDNA trnL-F region.

\section{Material and methods}

\section{Apple genotypes}

Eight apple genotypes (Benekli, Helesan, Hese, Ovacin, Seva Zer, Sıvi Şirin, Sıvi Tırş, Sohrık) from Malus domestica otor were analyzed in this study. The name of the apple genotypes is given in Table 1 .

Table 1. Total phenolic and total flavonoid contents of peel for different apple genotypes

\begin{tabular}{l|c|c}
\hline Apple genotypes & $\begin{array}{c}\text { TPC } \\
\text { (mg GAE/g) }\end{array}$ & $\begin{array}{c}\text { TFC } \\
(\mathbf{m g ~ R E} / \mathbf{g})\end{array}$ \\
\hline 1. Benekli & $3,75 \pm 1,64^{\mathrm{cd}}$ & $4,49 \pm 0,13^{\mathrm{e}}$ \\
2. Helesan & $12,21 \pm 1,25^{\mathrm{a}}$ & $7,98 \pm 0,26^{\mathrm{a}}$ \\
3. Hese & $5,22 \pm 0,83^{\mathrm{bc}}$ & $5,21 \pm 0,22^{\mathrm{bc}}$ \\
4. Ovvacin & $4,23 \pm 0,56^{\mathrm{bc}}$ & $4,79 \pm 0,16^{\mathrm{de}}$ \\
5. Seva Zer & $2,57 \pm 0,41^{\mathrm{d}}$ & $4,02 \pm 0,11^{\mathrm{f}}$ \\
6. Sıvi Şirin & $4,67 \pm 0,21^{\mathrm{bc}}$ & $5,01 \pm 0,38^{\mathrm{cd}}$ \\
7. Sivi Tirş & $4,87 \pm 0,20^{\mathrm{bc}}$ & $5,37 \pm 0,19^{\mathrm{bc}}$ \\
8. Sohrık & $5,78 \pm 0,31^{\mathrm{b}}$ & $5,47 \pm 0,17^{\mathrm{b}}$ \\
\hline
\end{tabular}

TPC - total phenolic content; TFC - total flavonoid content; GAE - gallic acid equivalents; RE - rutin equivalent. The results were expressed as mean \pm standard deviation. Means sharing the same letter in a column are not significantly different by Duncan's multiple range test at $\mathrm{P} \leq 0.01$ 
All genotypes were identified by specimen. The apples were collected during harvest seasons (June-August, 2013-2015). Fresh peel was manually separated from the pulp and seeds with the help of pens and forceps and then was dried until reaching a constant weight. The fresh peel was powdered with mortar and pestle by methanol $(80 \%)$ and was shaken at dark for a night. The extracts were evaporated by the rotary evaporator and solutions of $1 \mathrm{mg} / \mathrm{ml}$ concentration were prepared. For phylogenetic analysis, the leaves belonging to each apple genotypes were protected in silica gel and the samples were homogenized with liquid nitrogen and stored at $-20^{\circ} \mathrm{C}$.

\section{Preparation of apple genotypes}

The powdered peels from eight apple genotypes were weighted (1.0 gr) and mixed with methanol $(80 \%)$. The samples were homogenized with the homogenizer for 2 minutes and subjected to the ultrasound for five minutes. The extracts were shaken on an orbital shaker at midnight and evaporated to dryness. The concentration of all crude extracts was adjusted to the same value through addition of $80 \%$ methanol.

\section{Total phenol contents}

Total phenolic contents (TPC) of powdered apple peels were performed by methods involving Folin-Ciocalteu reagent and gallic acid as standard (Slinkard and Singleton, 1977). Extract solution $(0.1 \mathrm{ml})$ containing $1,000 \mathrm{mg}$ extract was taken in a tube, and 1 $\mathrm{ml}$ Folin-Ciocalteu reagent was added and the flask was shaken thoroughly. After 3 min, $1 \mathrm{ml}$ of solution of $6 \% \mathrm{Na}_{2} \mathrm{CO}_{3}$ was added and the mixture was allowed to stand for $1 \mathrm{~h}$ with intermittent shaking. Absorbance was measured at $760 \mathrm{~nm}$ with a Shimadzu UV mini 1240 spectrophotometer (Japan). The same procedure was repeated to all standard gallic acid solutions.

\section{Total flavonoid content}

The total flavonoid content was estimated using aluminum chloride colorimetric assay (Zhishen et al., 1999; Zou et al., 2004). The $0.5 \mathrm{ml}$ of test samples solution in methanol were mixed with $2 \mathrm{ml}$ of distilled water and $150 \mu \mathrm{l}$ of $5 \%$ sodium nitrate. After $6 \mathrm{~min}, 150 \mu \mathrm{l}$ of $10 \%$ aluminum chloride and $2 \mathrm{ml}$ of $1 \mathrm{M}$ sodium hydroxide were added and left at room temperature for $15 \mathrm{~min}$. The absorbance of mixtures was measured at $510 \mathrm{~nm}$. Rutin was used as a standard to determine flavonoid contents of the grape seed extracts.

\section{DPPH assay}

DPPH (2,2-diphenyl-1-picrylhydrazyl) assay was performed in accordance with (Villano et al., 2006). Concentrations were adjusted to 1,5 and $10 \mathrm{mg} / \mathrm{ml}$ respectively. Briefly, $1 \mathrm{ml}$ of sample was added to the freshly prepared $4 \mathrm{ml}$ of $0.01 \mathrm{mM} \mathrm{DPPH}$ solution (dissolved in methanol), incubated for $15 \mathrm{~min}$ in dark conditions and measured at $517 \mathrm{~nm}(E q .1)$.

DPPH activity $(\%$ incubation $)=\left(A_{\mathrm{C}}-A_{1}\right) / A_{\mathrm{C}} \times 100$

( $A_{C}$ : Control Absorbance, $A_{1}$ : Sample Absorbance) 


\section{Statistical analysis}

Results obtained were reported as mean \pm SD of triplicate measurements. Significance differences for multiple comparisons were determined by one way analysis of variance (ANOVA) followed by Duncan test with $\alpha=0.01$ using SPSS (version 20).

\section{DNA isolation, PCR condition and phylogenetic analysis}

DNA was extracted from leaf tissues of genotypes according to CTAB (cetyl trimethylammonium bromide) method (Doyle, 1987). DNA quality was checked on $1 \%$ agarose gel and then quantification was measured by using the Nanodrop (Thermo). To achieve the amplification of trnL-F region of chloroplast (cp) genome, PCR was performed in $25 \mu \mathrm{l}$ volume. That volume was occurred from $3 \mu 1$ (100 ng) DNA template $2,5 \mu 110 \mathrm{X}$ taq buffer, $3 \mu 1 \mathrm{MgCI}_{2}, 1 \mu \mathrm{l}$ forward, reverse primers and $10 \mathrm{mM}$ dNTP mix, 0,25 $\mu \mathrm{l}$ Taq polymerase and finally $13 \mu \mathrm{lddH_{2 }} \mathrm{O}$. PCR products were separated by gel electrophoresis on $1.5 \%$ agarose gels, containing ethidium bromide, and photographed under UV light in a gel doc system. PCR products of trnL-F region were sequenced by Iontek Company, Istanbul, Turkey.

\section{Alignment and phylogenetic analysis}

The sequences obtained were blasted (basic local alignment search tool) in NCBI (National Center for Biotechnology Information) database and percentage homology scores were assessed to identify apple genotypes. Phylogenetic trees were done with MEGA version 6 using a neighbor-joining algorithm with bootstrap analyses for 1,000 replicates.

\section{Results and discussion}

\section{Antioxidant properties}

\section{Total phenolics and flavonoids}

The total phenolic content (TPC) and the total flavonoid content of the apple peel of all genotypes, quantified as gallic acid equivalent and rutin respectively, are shown in Table 1. The TPC varied considerably depending on the genotype. Of all the apple genotypes, the highest TPC was observed in Helesan, whereas Seva Zer had the lowest TPC. In addition, the highest total phenolic content (TFC) was found in Helesan followed by Sohrik. As regards total flavonoid contents, they changed between 4,02 and 7,98. There was a significant difference at $\mathrm{p}<0.01$ between all samples for the total phenolic and flavonoid contents.

These results are incongruent with (Vieira et al., 2009; Manzoor et al., 2012) but in line with the results of (Wolfe et al., 2003; Faramarzi et al., 2014; Leahu and Ropciuc, 2013).

According to the results of previous studies (Awad and de Jager, 2000; Duda-Chodak et al., 2011; Escarpa and Gonzalez, 1998; Łata et al., 2009), it can be noted that some apple genotypes have higher TPC than others (Kalinowska et al., 2014). For example, the peel of 'Red Rome', 'Idared', 'Fiesta', 'Fuji', 'Gloster', 'McIntosh' and 'Pilot' contains higher amount of chlorogenic acid in comparison to other varieties, whereas 'Elan', 'Elstar' and 'Jonamac' show the lowest content of chlorogenic acid. 'Red 
Rome', 'Prima', 'Pilot' and 'Elstar' possess high amount of catechin and epicatechin in peel. 'Starking Delicious', 'Gloster', 'Golden Delicious', 'Granny Smith', 'Idared' and 'Monroe' possess high content of phloridzin. While the peel of 'McIntosh' and 'Reineta' are abundant in procyanidin B1, 'Elstar' and 'Idared' in procyanidin B2, 'Gloster', 'Idared', 'Lobo' and 'Elstar' are rich in procyanidin C1. The composition of the peel dependent on apple genotype differs significantly. However, most of the phloridzin, procyanidines $\mathrm{B} 2$ and $\mathrm{C} 1$, catechin and epicatechins are present in apple fruit (Carbone et al., 2011). The differences among TPCs can be attributed to the presence of the mixture of different cyanidin glycosides (Tsao et al., 2005; Wolfe et al., 2003) or to the biosynthesis pathway of phenolic compounds (Treutter, 2001; Wang et al., 2013). Fruit maturation also plays an important role on the concentration of the phenolic compounds in apple peel (Treutter, 2001). Moreover, since all eight apple genotypes tested in the present study were grown in the same region with similar ecological conditions, the variation in total phenolics and flavonoids demonstrates that the genetic variability may have given rise to the differences in the biosynthesis of phenolic secondary metabolites.

\section{DPPH radical scavenging activity}

The DPPH free radical is a constant free radical which has been utilized as a tool for determination of free radical scavenging activity of antioxidants (Acharya et al., 2012; Fenglin et al., 2004; Oyaizu, 1986). The results are presented in Table 2. According to DPPH scavenging activity assay results, the highest scavenging capacity was found in Hese extract followed by Sivi Şirin of $5 \mathrm{mg} / \mathrm{ml}$ concentration with a clear difference, and for all the genotypes studied these values ranged between 79,62 \% and 77,43\%.

Table 2. Free radical scavenging activity (Percentage) of 8 different apple genotypes in the concentrations of $5 \mathrm{mg} / \mathrm{ml}$ by $\mathrm{DPPH}$ reduction

\begin{tabular}{c|c}
\hline Genotypes & Inhibition $(\boldsymbol{\%})$ \\
\hline Benekli & 77,43 \\
Helesan & 74,92 \\
Hese & 79,62 \\
Ovacin & 75,86 \\
Seva Zer & 77,74 \\
Sivi Şirin & 78,06 \\
Sıvi Tırş & 77,43 \\
Sohrık & 77,74 \\
\hline
\end{tabular}

Our findings are in disagreement with some research results (Jelodarian et al., 2012; Yoshizawa et al., 2005), but consistent with some others (Manzoor et al., 2012; Sownthariya and Shanthi, 2015).

It has been noted that free radical scavenging activity of the plant based food (fruits and vegetables) extracts principally arise from phenolic compounds, which are largely distributed in the epidermal tissue (Cheng et al., 2006; D'Abrosca et al., 2007). Furthermore, the method used for determination of antioxidant activity has 
various effects on results. It should be mentioned that antioxidant activity can be affected by the solvent type. As different extraction solvents differ greatly in terms of polarity, their extracting abilities for different compounds are different (Kong et al., 2012; Li et al., 2014; Liu et al., 2009; Razali et al., 2012). For example, Li et al. (2014) reported that DPPH values of 10 crab apples (Malus wild species) ethanol extracts were found 6 times higher than ethyl acetate extracts on average. Apart from the solvent type used, the extraction method used is another important parameter. He et al. (2015) used three different extractions methods (microwaveassisted extraction, ultrasound-assisted extraction and water bath extraction) for the extraction of apple polyphenols and concluded that microwave-assisted extraction was much better than the other two methods.

\section{Molecular phylogeny of apple genotypes using the chloroplast trnL-F DNA sequences}

Chloroplast DNA (cpDNA) is a robust tool for inferring the interspecific relationship between the plant taxon. To study the genetic relationship of the interspecific genotypes between trnL (UAA) 3'exon and trnF (GAA) gene is known quite informative (Ashworth, 2017; Taberlet et al., 1991). In this study, a molecular phylogenetic analysis of eight apple genotypes commonly consumed in Turkey was performed by using trnLF cpDNA sequences.

trnL-F cpDNA sequences are usually used for molecular classification plant cultivars, genotypes, species and interspecies analyses (Ashworth, 2017). In our study, ML and NJ phylogenetic analysis of trnL-F sequences showed almost the same profile but only NJ tree with Mespilus germenica out group is presented here (Figure 1).

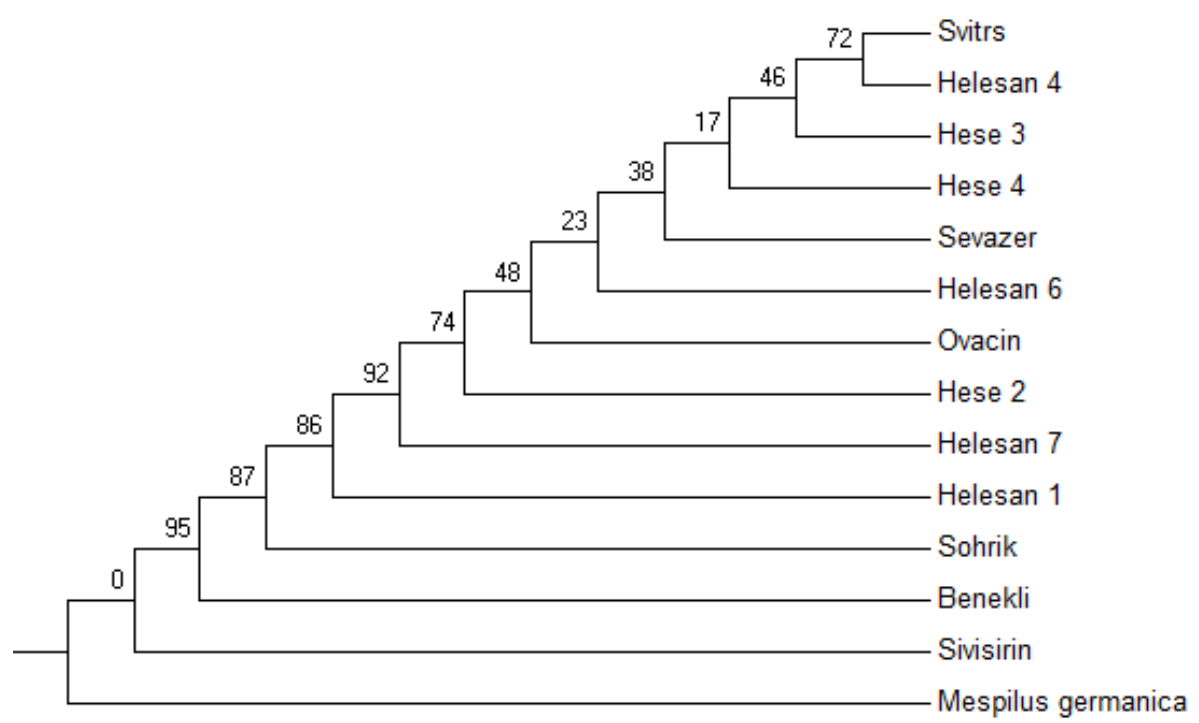

Figure 1. Phylogenetic analysis of apple genotypes based on trnL-F chloroplast region with Neighbour-Joining method (numbers on branches show the bootstrap value)

Based on the $\mathrm{NJ}$ tree, genotypes are comprised of three main clades with a robust bootstrap (95) value. The widest of these three clades comprised the Sivitırs, Helesan 4, Hese 3, Hese 4, Sevazer, Helesan 6, Ovacin, Hese 2, Helesan 7, Helesan 1 and Sohrik genotypes. The second clade comprised only Benekli genotype and Sivisirin constituted the obviously separated clade (Figure 1). In the first clade, it was found that all replicate 
genotypes fell within the same group. Thus, genetic relationships of the apple genotypes based on trnL-F region were estimated to be quite effective. There are many phylogenetic studies that found that trnL-F cpDNA region was quite effective for separating plant genotypes (Ashworth, 2017; Zhang et al., 2014; Zhang et al., 2016). In the present study, polymorphism of trnL-F analysis was found to be more informative. It produced fairly clear dendrogram that explains all apple genotypes according to morphological character and aromatic properties. To support this point in our analysis, Sivisirin apple genotype, which has different aromatic feature (it is known so sweet), comprised an evidently separated clade (Figure 1). Furthermore, this genotype has the highest inhibition rate (78 \%) in DPPH analysis (Table 2). Sivisirin also showed a different value according to other genotypes in TPC and TFC analysis (Table 1).

\section{Conclusion}

This study was carried out to determine the biochemical and molecular relationships of eight apple genotypes that were collected from different regions of Turkey. The relevant genotypes show quite variation in biochemical characteristics and molecular systematic analysis. "Helesan", one of the genotypes, was the best graded genotype based on the high content of the total phenolic $(12,21 \pm 1,25)$ and total flavonoid $(7,98 \pm 0,26)$ content. As a result of the molecular analysis, which is granted as one of the main points of the study, genotypes are comprised of three main clades with a robust bootstrap (95) value. The widest of these three clades comprised the Sivitırs, Helesan 4, Hese 3, Hese 4, Sevazer, Helesan 6, Ovacin, Hese 2, Helesan 7, Helesan 1 and Sohrik genotypes. The second clade comprised only the Benekli genotype and Sivisirin comprised the obviously separated clade. Consequently, it is expected that this study will be a useful step for the molecular biotechnology breeding in horticulture agriculture. These local apple genotypes can also be assessed as a quite important source of genes for apple breeding program and for the production of value added apple genotypes. Hence, further studies are recommended on local and ancient genotypes to identify their biological potentials.

\section{REFERENCES}

[1] Acharya, S., Acharya, N., Bhangale, J., Shah, S., Pandya, S. (2012): Antioxidant and hepatoprotective action of Asparagus racemosus Willd. root extracts. - Indian Journal of Experimental Biology 50(11): 795-801.

[2] Arts, I. C., Hollman, P. C. (2005): Polyphenols and disease risk in epidemiologic studies. - The American Journal of Clinical Nutrition 81: 317S-325S.

[3] Ashworth, V. E. (2017): Revisiting phylogenetic relationships in Phoradendreae (Viscaceae): utility of the trnL-F region of chloroplast DNA and presence of a homoplasious inversion in the intergenic spacer. - Botany 95: 247-258.

[4] Awad, M. A., de Jager, A. (2000): Flavonoid and chlorogenic acid concentrations in skin of 'Jonagold'and 'Elstar'apples during and after regular and ultra low oxygen storage. Postharvest Biology and Technology 20: 15-24.

[5] Boyer, J., Liu, R. H. (2003): Antioxidants of apples. - New York Fruit Quarterly 11: 11-15.

[6] Carbone, K., Giannini, B., Picchi, V., Scalzo, R. L., Cecchini, F. (2011): Phenolic composition and free radical scavenging activity of different apple varieties in relation to the cultivar, tissue type and storage. - Food Chemistry 127: 493-500. 
[7] Cheng, Z. et al. (2006): Effects of postharvest treatment and heat stress on availability of wheat antioxidants. - Journal of Agricultural and Food Chemistry 54: 5623-5629.

[8] D’Abrosca, B., Pacifico, S., Cefarelli, G., Mastellone, C., Fiorentino, A. (2007): 'Limoncella' apple, an Italian apple cultivar: Phenolic and flavonoid contents and antioxidant activity. - Food Chemistry 104: 1333-1337.

[9] Duarte-Almeida, J. M., dos SANTOS, R. J., Genovese, M. I., Lajolo, F. M. (2006): Avaliação da atividade antioxidante utilizando sistema b-caroteno/ácido linoléico e método de seqüestro de radicais DPPH. - Ciência e Tecnologia de Alimentos 26: 446452.

[10] Duda-Chodak, A., Tarko, T., Tuszyński, T. (2011): Antioxidant activity of apples - an impact of maturity stage and fruit part. - Acta Scientiarum Polonorum Technologia Alimentaria 10: 443-454.

[11] Escarpa, A., Gonzalez, M. (1998): High-performance liquid chromatography with diodearray detection for the determination of phenolic compounds in peel and pulp from different apple varieties. - Journal of Chromatography A 823: 331-337.

[12] Faramarzi, S. et al. (2014): Comparison of phenolic compounds' content and antioxidant activity between some native Iranian apples and standard cultivar 'Gala'. - Journal of Agricultural Science and Technology 16: 1601-1611.

[13] Fenglin, H., Ruili, L., Liang, M. (2004): Free radical scavenging activity of extracts prepared from fresh leaves of selected Chinese medicinal plants. - Fitoterapia 75: 14-23.

[14] Goulão, L., Oliveira, C. M. (2001): Molecular characterisation of cultivars of apple (Malus $\times$ domestica Borkh.) using microsatellite (SSR and ISSR) markers. - Euphytica 122: 81-89.

[15] He, Y., Lu, Q., Liviu, G. (2015): Effects of extraction processes on the antioxidant activity of apple polyphenols. - CyTA-Journal of Food 13: 603-606.

[16] Henríquez, C. et al. (2010): Determination of antioxidant capacity, total phenolic content and mineral composition of different fruit tissue of five apple cultivars grown in Chile. Chilean Journal of Agricultural Research 70(4): 523-536

[17] Hokanson, S., Lamboy, W., Szewc-McFadden, A., McFerson, J. (2001): Microsatellite (SSR) variation in a collection of Malus (apple) species and hybrids. - Euphytica 118: 281-294.

[18] Jelodarian, S., Haghir Ebrahimabadi, A., Khalighi, A., Batooli, H. (2012): Evaluation of antioxidant activity of Malus domestica fruit extract from Kashan area. - Avicenna Journal of Phytomedicine 2: 139-145.

[19] Kalinowska, M., Bielawska, A., Lewandowska-Siwkiewicz, H., Priebe, W., Lewandowski, W. (2014): Apples: content of phenolic compounds vs. variety, part of apple and cultivation model, extraction of phenolic compounds, biological properties. Plant Physiology and Biochemistry 84: 169-188.

[20] Kong, K. W., Mat-Junit, S., Aminudin, N., Ismail, A., Abdul-Aziz, A. (2012): Antioxidant activities and polyphenolics from the shoots of Barringtonia racemosa (L.) Spreng in a polar to apolar medium system. - Food Chemistry 134: 324-332.

[21] Lampe, J. W. (1999): Health effects of vegetables and fruit: assessing mechanisms of action in human experimental studies. - The American Journal of Clinical Nutrition 70: 475s-490s.

[22] Lata, B., Trampczynska, A., Paczesna, J. (2009): Cultivar variation in apple peel and whole fruit phenolic composition. - Scientia Horticulturae 121: 176-181.

[23] Leahu, A, Ropciuc, S. (2013): Radical scavenging activity and total phenolic contentcomparison between apple and red grape. - Analele Universităţii din Oradea, Fascicula: Ecotoxicologie, Zootehnie şi Tehnologii de Industrie Alimentară 12: 239-248.

[24] Li, N., Shi, J., Wang, K. (2014): Profile and antioxidant activity of phenolic extracts from 10 crabapples (Malus wild species). - Journal of Agricultural and Food Chemistry 62: 574-581. 
[25] Liu, S.-C., Lin, J.-T., Wang, C.-K., Chen, H.-Y., Yang, D.-J. (2009): Antioxidant properties of various solvent extracts from lychee (Litchi chinenesis Sonn.) flowers. Food Chemistry 114: 577-581.

[26] Manzoor, M., Anwar, F., Saari, N., Ashraf, M. (2012): Variations of antioxidant characteristics and mineral contents in pulp and peel of different apple (Malus domestica Borkh.) cultivars from Pakistan. - Molecules 17: 390-407.

[27] Oyaizu, M. (1986): Studies on products of browning reaction - antioxidative activities of products of browning reaction prepared from glucosamine. - Eiyogaku zasshi $=$ Japanese Journal of Nutrition and Dietetics 44(6): 307-315.

[28] Panzella, L., Petriccione, M., Rega, P., Scortichini, M., Napolitano, A. (2013): A reappraisal of traditional apple cultivars from Southern Italy as a rich source of phenols with superior antioxidant activity. - Food Chemistry 140: 672-679.

[29] Patzak, J., Paprštein, F., Henychová, A., Sedlák, J. (2012): Genetic diversity of Czech apple cultivars inferred from microsatellite markers analysis. - Horticultural Science (Prague) 39: 149-157.

[30] Pirie, M. D., Vargas, M. P. B., Botermans, M., Bakker, F. T., Chatrou, L. W. (2007): Ancient paralogy in the cpDNA trnL-F region in Annonaceae: implications for plant molecular systematics. - American Journal of Botany 94: 1003-1016.

[31] Quandt, D. et al. (2004): Molecular evolution of the chloroplast trnL-F region in land plants. - Monographs in Systematic Botany from the Missouri Botanical Garden 98: 13-37.

[32] Razali, N., Mat-Junit, S., Abdul-Muthalib, A. F., Subramaniam, S., Abdul-Aziz, A. (2012): Effects of various solvents on the extraction of antioxidant phenolics from the leaves, seeds, veins and skins of Tamarindus indica L. - Food Chemistry 131: 441-448.

[33] Rivero-Pérez, M. D., MUNiz, P., González-Sanjosé, M. L. (2007): Antioxidant profile of red wines evaluated by total antioxidant capacity, scavenger activity, and biomarkers of oxidative stress methodologies. - Journal of Agricultural and Food Chemistry 55: 54765483.

[34] Scalbert, A., Manach, C., Morand, C., Rémésy, C, Jiménez, L. (2005): Dietary polyphenols and the prevention of diseases. - Critical Reviews in Food Science and Nutrition 45: 287-306.

[35] Slinkard, K, Singleton, V. L. (1977): Total phenol analysis: automation and comparison with manual methods. - American Journal of Enology and Viticulture 28: 49-55.

[36] Smolik, M., Rzepka-Plevneš, D., Stankiewicz, I., Chełpiński, P., Kowalczys, K. (2004): Analysis of genetic similarity of apple tree cultivars. - Folia Horticulturae 16: 87-94.

[37] Sownthariya, C., Shanthi, P. (2015). Free-radical scavenging activity of some fresh and refrigerated fruits. - International Journal of Pharma and Bio Sciences 6(3): B824-B830.

[38] Taberlet, P., Gielly, L., Pautou, G., Bouvet, J. (1991): Universal primers for amplification of three non-coding regions of chloroplast DNA. - Plant Molecular Biology 17: 11051109.

[39] Treutter, D. (2001): Biosynthesis of phenolic compounds and its regulation in apple. Plant Growth Regulation 34: 71-89.

[40] Tsao, R., Yang, R., Xie, S., Sockovie, E., Khanizadeh, S. (2005): Which polyphenolic compounds contribute to the total antioxidant activities of apple? - Journal of Agricultural and Food Chemistry 53: 4989-4995.

[41] Vieira, F. G. K. et al. (2009): Physico-chemical and antioxidant properties of six apple cultivars (Malus domestica Borkh) grown in southern Brazil. - Scientia Horticulturae 122: 421-425.

[42] Villano, D., Fernández-Pachón, M., Troncoso, A., García-Parrilla, M. (2006): Influence of enological practices on the antioxidant activity of wines. - Food Chemistry 95: 394404. 
[43] Wang, L. et al. (2013): The effect of fruit bagging on the color, phenolic compounds and expression of the anthocyanin biosynthetic and regulatory genes on the 'Granny Smith' apples. - European Food Research and Technology 237: 875-885.

[44] Wolfe, K., Wu, X., Liu, R. H. (2003): Antioxidant activity of apple peels. - Journal of Agricultural and Food Chemistry 51: 609-614.

[45] Wu, J. et al. (2007): Chemical compositional characterization of some apple cultivars. Food Chemistry 103: 88-93.

[46] Yoshizawa, Y. et al. (2005): Comparison of antiproliferative and antioxidant properties among nineteen apple cultivars. - Horticultural Science 40: 1204-1207.

[47] Zhang, J.-Q., Meng, S.-Y., Wen, J., Rao, G.-Y. (2014): Phylogenetic relationships and character evolution of Rhodiola (Crassulaceae) based on nuclear ribosomal ITS and plastid trnL-F and psbA-trnH sequences. - Systematic Botany 39: 441-451.

[48] Zhang, L. et al. (2016): Circumscription and phylogeny of the fern family Tectariaceae based on plastid and nuclear markers, with the description of two new genera: Draconopteris and Malaifilix (Tectariaceae). - Taxon 65: 723-738.

[49] Zhishen, J., Mengcheng, T., Jianming, W. (1999): The determination of flavonoid contents in mulberry and their scavenging effects on superoxide radicals. - Food Chemistry 64: 555-559.

[50] Zou, Y., Lu, Y., Wei, D. (2004): Antioxidant activity of a flavonoid-rich extract of Hypericum perforatum L. in vitro. - Journal of Agricultural and Food Chemistry 52: 5032-5039. 